\title{
Determining the reuse of metal mine wastes based on leaching test and human health risk assessment
}

\author{
Won Jung Ju${ }^{1}$, Sun Kyung Hwang ${ }^{2}$, Eun Hea $\mathrm{Jho}^{2+}$, Kyoungphile $\mathrm{Nam}^{1}$ \\ ${ }^{1}$ Department of Civil and Environmental Engineering, Seoul National University, Seoul 08826, Republic of Korea \\ ${ }^{2}$ Department of Environmental Science, Hankuk University of Foreign Studies, Yongin 17035, Republic of Korea
}

\begin{abstract}
Meeting the regulations based on the short-term leaching tests may not necessarily assure the environmental and human health safety of reusing mine wastes. This study investigated heavy metal leachability of four metal mine waste samples (e.g., $\mathrm{Z}, \mathrm{Y}, \mathrm{H}$, and $\mathrm{M}$ ) and human health risk of reusing them as construction materials. The heavy metal leachability did not depend on the total heavy metal contents. For example, the $\mathrm{Z}$ sample contained greater amounts of $\mathrm{As}$ and $\mathrm{Fe}$ than $\mathrm{Zn}$, but the leachates contained only $\mathrm{Zn}$ at a detectable level. This can be attributed to the crystalline structure and heavy metal fractions of the mine wastes. The leaching test results suggested that the four mine waste samples are potentially reusable. But the $\mathrm{Z}$ and $\mathrm{M}$ samples reused in industrial areas imposed carcinogenic risks. This was largely attributed to As that is exposed via dermal contact. The $\mathrm{Y}$ and $\mathrm{H}$ samples reused in residential areas imposed carcinogenic risk. The major exposure route was the ingestion of crops grown on the mine wastes and $\mathrm{Cr}$ was the major concern. The two-stage assessment involving leaching tests and risk assessment can be used to promote safe reuse of mine wastes.
\end{abstract}

Keywords: Heavy metal, Human health risk, Leachability, Mine waste, Reuse

\section{Introduction}

Mine wastes generated during beneficiation of the extracted ore are often heaped and stored without any treatment near mining sites. These mine wastes are prone to metal leaching, which may often lead to acid mine drainage (AMD) generation, and this can cause environmental contamination near mining sites $[1,2]$. The leachate generated from mine wastes can have impacts on surrounding environments and nearby residents due to their low $\mathrm{pH}$ and/or harmful heavy metal contents [3, 4]. Conventional treatment methods often involve post-treatment of the generated AMD from mine wastes or the contaminated water and/or soil by AMD [5]. Also, potentials for exposure of mine wastes to air or water and consequential oxidation of sulfide minerals such as pyrite $\left(\mathrm{FeS}_{2}\right)$ contained in mine wastes and AMD generation can be removed by covering mine wastes or by removing potential contaminants in mine wastes [6].

The growing movement towards reusing and recycling of solid wastes is promoting research on beneficial reuses of mine wastes as well. One of the major environmental issues in mine waste reuse is leaching of various heavy metals contained in mine wastes, in particular, metal mine wastes. Heavy metal concentrations in the leachates from solid wastes in Republic of Korea are regulated based on the short-term leaching tests. However, meeting the regulations based on short-term leaching tests does not necessarily mean that it is safe to reuse mine wastes. The continuous release of leachates from mine wastes with higher metal contents may result in contamination of the surrounding soil environment. The soil impacted by mine wastes can have phytotoxicity $[7,8]$ and human health risk [9, 10]. Therefore, in order to promote the reuse of mine wastes, it is necessary to prepare a new framework that can assess the environmental and human health safety.

Heavy metal leaching from mine wastes is highly dependent on the proportions of silicate, acidic minerals, and organic matter that constitute mine wastes and the leachability of biogenic elements ( $\mathrm{K}, \mathrm{Na}, \mathrm{Cl}^{-}, \mathrm{NO}_{3}{ }^{-}$) [11]. For example, leaching of heavy metals is likely to be lower for the mine wastes with lower sulfide mineral contents as the generation of acid that will dissolve
This is an Open Access article distributed under the terms of the Creative Commons Attribution Non-Commercial License (http://creativecommons.org/licenses/by-nc/3.0/) which permits unrestricted non-commercial use, distribution, and reproduction in any medium, provided the original work is properly cited.

Copyright (C) 2019 Korean Society of Environmental Engineers
Received December 15, 2017 Accepted June 20, 2018

${ }^{\dagger}$ Corresponding author

Email: ehjho@hufs.ac.kr

Tel: +82-31-330-4528 Fax: +82-31-330-4529

ORCID: 0000-0003-0098-7338 
heavy metals will be less [12]. The current regulation determines the reusability of solid wastes (e.g., mine waste) based on the contaminant concentrations in the leachates; however, mine wastes are not readily reused even though they satisfy the regulations. This study used the metal mine waste samples collected in different places of Republic of Korea to investigate the leachability of heavy metals, the ecological toxic effects of the leachates, and the human health risk of reusing the mine waste samples.

This study aims at providing a new framework that can promote the reuse of mine wastes, and a two-stage assessment method involving short-term leaching tests and human health risk assessment is suggested. This method can be used to determine the reusability of mine wastes considering both the current regulations on leachates and the information on human health risk, and promote the safe reuse of mine wastes.

\section{Materials and Methods}

\subsection{Preparation of Mine Waste Samples}

Mine waste samples were collected from an operating lead $(\mathrm{Pb})$ and zinc ( $\mathrm{Zn})$ mine (hereafter referred to as $\mathrm{Z}$ mine, located in Gyeongsangbuk-do province, South Korea), two operating magnetite mines (hereafter referred to as $\mathrm{Y}$ mine and $\mathrm{H}$ mine, located in Gangwon-do province, South Korea), and an operating molybdenum mine (hereafter referred to as $\mathrm{M}$ mine, located in Chungcheongbuk-do province, South Korea). Mine wastes were sampled after the mineral dressing step, dried at room temperature, and sealed to reduce contact with air until the use.

\subsection{Mine Waste Characteristics}

The crystal structures of the mine waste samples were analyzed using the X-ray powder diffraction (XRD) (D8 Advance, Bruker, Germany). The United States Environmental Protection Agency (USEPA) 3052 method, a microwave-assisted acid digestion method for extracting residual elements in soil, was used to analyze total heavy metal contents in the mine waste samples [13]. Briefly, $0.5 \mathrm{~g}$ of each mine waste sample was placed in a mixture of $9 \mathrm{~mL} \mathrm{HNO}_{3}, 3 \mathrm{~mL} \mathrm{HF}, 2 \mathrm{~mL} \mathrm{HCl}$, and $1 \mathrm{~mL} \mathrm{H}_{2} \mathrm{O}_{2}$ in a Teflon tube. The mine waste samples were dissolved by using a microwave (MARS 6 230/60, CEM, US), which was programmed to raise its temperature to $180^{\circ} \mathrm{C}$ within $5.5 \mathrm{~min}$ and then maintained at $180^{\circ} \mathrm{C}$ for $9.5 \mathrm{~min}$. The samples were cooled down to room temperature, and the digested samples were filtered through $0.45 \mu \mathrm{m}$ GHP syringe filters for further analysis. The sequential extraction procedure suggested by Tessier et al. [14] was used to identify metals bound to exchangeable fraction, bound to carbonate, and bound to $\mathrm{Fe}$ and $\mathrm{Mn}$ oxides. Briefly, $1 \mathrm{M} \mathrm{MgCl}_{2}$ (pH 7), $1 \mathrm{M}$ sodium acetate (pH 5.0 adjusted with acetic acid), and $0.04 \mathrm{M} \mathrm{NH}_{2} \mathrm{OH} \cdot \mathrm{HCl}$ in $25 \%$ acetic acid (v:v) were used to extract metals bound to exchangeable fraction, carbonate, and $\mathrm{Fe}$ and $\mathrm{Mn}$ oxides, respectively. The extracts obtained were filtered through $0.45 \mu \mathrm{m}$ GHP syringe filters, and analyzed for arsenic (As), Pb, cadmium (Cd), Zn, copper $(\mathrm{Cu})$, nickel (Ni), and chromium (Cr). The $\mathrm{pH}$ of the mine waste samples was measured using the 5-star portable meter (Thermo Fisher Scientific) equipped with a $\mathrm{pH}$ probe (8102BNUWP).

\subsection{Heavy Metal Leaching Tests from the Mine Waste Samples}

The heavy metal leaching potentials from the four mine waste samples were tested using the Korea Standard Test Methods for Solid Wastes (hereafter, referred to as STM) provided by the Korea Ministry of Environment (KMOE) [15]. Briefly, 100 $\mathrm{g}$ of the mine waste sample, passed through a $2 \mathrm{~mm}$ sieve, was mixed with $\mathrm{pH}$-adjusted distilled water $(\mathrm{pH}$ 5.8-6.3 with $\mathrm{HCl})$ at a ratio of $1: 10(\mathrm{w}: \mathrm{v})$. The mixture was shaken for $6 \mathrm{~h}$ at $200 \mathrm{rpm}$ with 4-5 $\mathrm{cm}$ of amplitude (at room temperature), and then centrifuged at $12,000 \mathrm{~g}$ for $15 \mathrm{~min}$. The heavy metal content of the filtered supernatant $(0.45 \mu \mathrm{m}$ GHP) was analyzed.

To determine the heavy metal leachability of the mine waste samples when they are exposed to acidic rainfall, the USEPA 1312 method (Synthetic Precipitation Leaching Procedure; hereafter referred to as SPLP), which was designed to simulate in-situ exposure of materials to slightly acidic rainfall, was used [16]. The mine waste samples, passed through a $9.5 \mathrm{~mm}$ sieve, were mixed with the leaching solution (i.e., distilled water with $\mathrm{pH}$ adjusted to $4.2 \pm 0.05$ using a mixture of $\mathrm{H}_{2} \mathrm{SO}_{4}: \mathrm{HNO}_{3}$ at $60: 40$ $(\mathrm{w}: \mathrm{w})$ ) at a ratio of $1: 20(\mathrm{w}: \mathrm{v})$. The mixture was shaken on a rotary agitator ( $30 \mathrm{rpm}, 23 \pm 2^{\circ} \mathrm{C}$ ) for $18 \mathrm{~h}$, and then centrifuged at $12,000 \mathrm{~g}$ for $15 \mathrm{~min}$. The supernatant was filtered through a $0.45 \mu \mathrm{m}$ GHP syringe filter for analysis of its heavy metal content (As, Pb, Cd, Zn, Cu, Ni, iron (Fe), Cr).

\subsection{Toxic Effects of Mine Waste Leachates}

The acute toxicities of the leachates generated using the STM and SPLP were determined by using Daphnia magna (D. magna) as a test species. D. magna was exposed to the leachates for $24 \mathrm{~h}$ and $48 \mathrm{~h}$ in accordance with the acute toxicity test method described in the Korea Standard Test Method for Water Quality [17]. The toxic unit (TU) was evaluated using the TOXCAL program (Tidepool Scientific Software, USA). Assuming that the leachates get to a nearby water system without considering dilution effect, the determined TU values were compared with the Korea Effluent Water Quality Standards [18].

\subsection{Human Health Risk of Reusing Mine Wastes}

The in vitro bioavailability of heavy metals contained in the mine waste sampels was determined by using the stomach-phase extraction test developed by Solubility/Bioavailability Consortium (SBRC) [19]. Briefly, $1 \mathrm{~g}$ of the mine waste sample, passed through a $150 \mu \mathrm{m}$ sieve, was mixed with $100 \mathrm{~mL}$ of synthetic gastric juice, which is $0.4 \mathrm{M}$ glycine adjusted to $\mathrm{pH} 1.5$ with $\mathrm{HCl}$. The mixture was agitated $\left(38^{\circ} \mathrm{C}, 200 \mathrm{rpm}\right)$ for $1 \mathrm{~h}$, and then centrifuged at $12,000 \mathrm{~g}$ for $15 \mathrm{~min}$. The supernatant was filtered through a $0.45 \mu \mathrm{m}$ GHP syringe filter for its heavy metal content analysis. The total heavy metal contents and the SBRC extracted heavy metal concentrations were then used to estimate the carcinogenic and non-carcinogenic human health risks, following the procedure described in the Soil Environment Conservation Act of 
Republic of Korea with modification [20]. Risk assessment was carried out assuming that the mine waste samples were reused in industrial and residential areas.

\subsection{Heavy Metal Concentration Analyses}

The concentrations of heavy metals/metalloids (i.e., Cr, Fe, Ni, $\mathrm{Cu}, \mathrm{Zn}, \mathrm{As}, \mathrm{Cd}, \mathrm{Pb}$ ) in the extracts obtained from the total heavy metal content analysis and SBRC test and in the leachates obtained from the leaching tests were analyzed by using Inductively Coupled Plasma-Optical Emission Spectrometer (ICP-OES) (ICAP 7400 DUO, Thermo Scientific, US). The detection limit of each element analyzed was as follows: As $0.089 \mathrm{mg} \mathrm{L}^{-1}$, Cd $0.015 \mathrm{mg} \mathrm{L}^{-1}$, Cr $0.010 \mathrm{mg} \mathrm{L}^{-1}$, Cu $0.005 \mathrm{mg} \mathrm{L}^{-1}$, Fe $0.007 \mathrm{mg}$ $\mathrm{L}^{-1}$, Ni $0.0134 \mathrm{mg} \mathrm{L}^{-1}, \mathrm{~Pb} 0.065 \mathrm{mg} \mathrm{L}^{-1}$, and $\mathrm{Zn} 0.004 \mathrm{mg} \mathrm{L}^{-1}$.

\section{Results and Discussion}

\subsection{Potential Contaminants in the Mine Waste Samples}

The total heavy metal contents of the four metal mine waste samples are shown in Table 1. The types and amounts of heavy metals contained in the different metal mine waste samples varied significantly depending on the types of mines (Table 1). For example, the $\mathrm{Pb}$ and $\mathrm{Zn}$ contents of the $\mathrm{Z}$ mine waste sample were relatively higher than the other mine waste samples since the $\mathrm{Z}$ mine produces $\mathrm{Pb}$ and $\mathrm{Zn}$ (Table 1). The $\mathrm{M}$ and $\mathrm{H}$ mine waste samples contained relatively higher concentrations of $\mathrm{Fe}$ than other heavy metals (Table 1). Also, the Fe content was the highest in the $\mathrm{Y}$ mine waste as the $\mathrm{Y}$ mine produces magnetite (Table 1). The major heavy metals contained in the mine waste samples were dependent on the metal that each mine produces. The high heavy metal contents of the studied mine waste samples may limit the reuse of mine wastes, if they are released as leachates.

\subsection{Heavy Metal Leaching from the Mine Waste and Leachate Toxicity}

The high heavy metal contents of the mine waste samples do not necessarily mean higher leachability of heavy metals from the mine waste samples. The heavy metal concentrations of the STM and SPLP leachates generated from the mine waste samples and their toxic effects on D. magna are shown in Table 2. Generally, the heavy metal concentrations of the STM and SPLP leachates were lower than the detection limits (Table 2). With the detected heavy metals, their concentrations were lower than the regulation levels given in the Korea Waste Control Act that need to be met in order to reuse any waste materials (Table 2). Only the STM and SPLP leachates from the $Z$ mine waste sample contained a detectable level of Zn (Table 2), although the amounts of the other constituents such as As and Fe were greater than that of Zn (Table 1). Also, the SPLP leachate of the Y mine waste contained a detectable level of Fe (Table 2).

The low heavy metal concentrations in the leachates can be attributed to the $\mathrm{pH}$ conditions of the leaching solutions. Heavy metal leachability at neutral or alkaline $\mathrm{pH}$ conditions is generally lower than that at acidic $\mathrm{pH}$ conditions [21]. The average initial $\mathrm{pH}$ of the leaching solution was 5.8 for the STM, but the final $\mathrm{pH}$ of the leaching solution was increased to 7.0 for the $\mathrm{Z}$ mine waste, 8.7 for the $\mathrm{M}$ mine waste, 8.9 for the $\mathrm{Y}$ mine waste, and 9.2 for the $\mathrm{H}$ mine waste. The increase in the $\mathrm{pH}$ of the leaching solution can be expected, as all the four mine waste samples contained $\mathrm{CO}_{3}$ - or OH-bearing minerals, which can potentially contribute to the $\mathrm{pH}$ increases (Table 3). Among the four mine waste samples, only the $\mathrm{Z}$ mine waste contained a sulfur-bearing mineral, pyrite, and the final $\mathrm{pH}$ of the $\mathrm{Z}$ mine waste leachate showed the smallest increase in the $\mathrm{pH}$. This may be attributed to the generation of acid due to sulfur-bearing minerals such as pyrite [12].

The heavy metal concentrations in the $\mathrm{Z}$ mine waste leachate did not depend on the total heavy metal contents of the $\mathrm{Z}$ mine waste (Table 1 and Table 2), and this can be attributed to the crystal structures of the $\mathrm{Z}$ mine waste (Table 3 ). The $\mathrm{Z}$ mine waste contained higher amounts of As and Fe than $\mathrm{Zn}$, but the leachate only contained a detectable level of Zn. Based on the crystal structure of the $\mathrm{Z}$ mine waste sample as shown in Table 3, As and Fe are found in minerals having crystalline structures such as pyrite, merrihueite $\left((\mathrm{K}, \mathrm{Na})_{2}(\mathrm{Fe}, \mathrm{Mg})_{5} \mathrm{Si}_{12} \mathrm{O}_{30}\right)$, butlerite $\left(\mathrm{FeSO}_{4}(\mathrm{OH}) \cdot 2 \mathrm{H}_{2} \mathrm{O}\right)$, and tennantite $\left(\mathrm{Cu}_{6}\left(\mathrm{Cu}_{0.48} \mathrm{Fe}_{5.52}\right)\right.$ $\mathrm{As}_{4} \mathrm{~S}_{13}$ ), while $\mathrm{Zn}$ is not observed in minerals having crystalline structures. This suggests that the Zn leachability may be greater than the As or Fe leachability, because the crystalline form is generally more stable than the amorphous counterpart, indicating that it requires a higher energy to break its chemical structure. In addition, based on the Tessier's sequential extraction, the readily soluble amounts of $\mathrm{Zn}$ and As (i.e., the sum of the exchangeable and carbonate-bound fractions) were $1.6 \%$ and $0.29 \%$ of the total content (Table 4). This indicates that $\mathrm{Zn}$ is more readily dissolved than As. Overall, the crystalline structures and the heavy metal fractions are more likely to influence the

Table 1. Heavy Metals Contained in the Mine Wastes Used in This Study (Unit: $\mathrm{mg} \mathrm{kg}^{-1}$ )

\begin{tabular}{|c|c|c|c|c|c|c|c|c|}
\hline $\begin{array}{c}\text { Mine } \\
\text { wastes }\end{array}$ & As & Cd & $\mathrm{Cr}$ & $\mathrm{Cu}$ & $\mathbf{F e}$ & $\mathrm{Ni}$ & $\mathbf{P b}$ & Zn \\
\hline $\mathrm{Z}$ & $45,424 \pm 5,620$ & $2,293 \pm 246$ & $118 \pm 11$ & $651 \pm 47$ & $88,943 \pm 6,539$ & $\mathrm{ND}^{1)}$ & $2,671 \pm 15$ & $14,851 \pm 541$ \\
\hline $\mathrm{M}$ & $401 \pm 259$ & 0.02 & $636 \pm 175$ & $158 \pm 78.3$ & $177,000 \pm 34,400$ & $258 \pm 117$ & $1,171 \pm 613$ & $2,330 \pm 111$ \\
\hline $\mathrm{Y}$ & ND & ND & $31.5 \pm 2.60$ & $26.6 \pm 4.69$ & $6,360 \pm 1,910$ & ND & $86.1 \pm 1.57$ & $390 \pm 4.98$ \\
\hline $\mathrm{H}$ & ND & $12.4 \pm 6.84$ & $141 \pm 5.48$ & ND & $103,000 \pm 7,540$ & $185 \pm 35.8$ & $1,180 \pm 88.0$ & $1,790 \pm 83.6$ \\
\hline
\end{tabular}

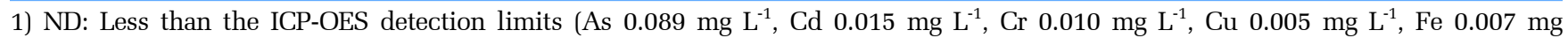
$\mathrm{L}^{-1}$, Ni $0.0134 \mathrm{mg} \mathrm{L}^{-1}$, Pb $0.065 \mathrm{mg} \mathrm{L}^{-1}$, Zn $0.004 \mathrm{mg} \mathrm{L}^{-1}$ ) 
Table 2. Heavy Metal Concentrations in the Leachates from the Mine Wastes (Unit: $\mathrm{mg} \mathrm{L}^{-1}$ except for TU) and Toxic Units (TU) of the Leachates Determined by Using Daphnia magna

\begin{tabular}{|c|c|c|c|c|c|c|c|c|c|c|c|}
\hline \multirow{2}{*}{$\begin{array}{c}\text { Mine } \\
\text { wastes }\end{array}$} & \multirow{2}{*}{ Leaching test } & \multirow{2}{*}{ As } & \multirow{2}{*}{ Cd } & \multirow{2}{*}{$\mathrm{Cr}$} & \multirow{2}{*}{$\mathrm{Cu}$} & \multirow{2}{*}{$\mathbf{F e}$} & \multirow{2}{*}{$\mathrm{Ni}$} & \multirow{2}{*}{$\mathrm{Pb}$} & \multirow{2}{*}{ Zn } & \multicolumn{2}{|c|}{ TU } \\
\hline & & & & & & & & & & $24 \mathrm{~h}$ & $48 \mathrm{~h}$ \\
\hline \multirow{2}{*}{$\mathrm{Z}$} & $\mathrm{STM}^{1)}$ & $\mathrm{ND}^{2)}$ & ND & ND & ND & ND & ND & ND & $0.123 \pm 0.010$ & 0 & 0.6 \\
\hline & $\mathrm{SPLP}^{3)}$ & $\mathrm{ND}$ & ND & ND & ND & ND & ND & ND & $0.052 \pm 0.016$ & 0.6 & 0.6 \\
\hline \multirow{2}{*}{$\mathrm{M}$} & STM & ND & ND & ND & ND & ND & ND & ND & ND & 0 & 0.2 \\
\hline & SPLP & ND & ND & ND & $\mathrm{ND}$ & ND & ND & ND & ND & 0 & 0 \\
\hline \multirow{2}{*}{$\mathrm{Y}$} & STM & ND & ND & ND & $\mathrm{ND}$ & ND & ND & ND & ND & 0 & 0.4 \\
\hline & SPLP & ND & ND & ND & $\mathrm{ND}$ & $0.015 \pm 0.004$ & ND & ND & ND & 0 & 0 \\
\hline \multirow{2}{*}{$\mathrm{H}$} & STM & $\mathrm{ND}$ & ND & ND & $\mathrm{ND}$ & ND & ND & ND & ND & 0 & 0.2 \\
\hline & SPLP & $\mathrm{ND}$ & ND & ND & $\mathrm{ND}$ & ND & ND & ND & ND & 0 & 0.2 \\
\hline \multicolumn{2}{|c|}{ Korea Waste Control Act } & 1.5 & 0.3 & Cr(VI) 1.5 & 3.0 & - & - & 3.0 & - & & - \\
\hline \multicolumn{2}{|c|}{$\begin{array}{l}\text { Korea Allowable Effluent } \\
\text { Water Quality Standards } \\
\text { (Clean area) }\end{array}$} & $<0.05$ & $<0.02$ & $<0.5$ & $<1$ & $<2$ & - & $<0.1$ & $<1$ & & $=1$ \\
\hline \multicolumn{2}{|c|}{$\begin{array}{l}\text { Korea Allowable Effluent } \\
\text { Water Quality Standards }{ }^{4)} \\
\text { (Area 1) }\end{array}$} & $<0.25$ & $<0.1$ & $<2$ & $<3$ & $<10$ & - & $<0.5$ & $<5$ & & $=2$ \\
\hline \multicolumn{2}{|c|}{$\begin{array}{l}\text { Water Quality Standards } \\
\text { (Area 2) }\end{array}$} & $<0.25$ & $<0.1$ & $<2$ & $<3$ & $<10$ & - & $<0.5$ & $<5$ & & $=2$ \\
\hline
\end{tabular}

1) STM: Standard Test Method for Solid Wastes

2) ND: Less than the ICP-OES detection limit (As $0.089 \mathrm{mg} \mathrm{L}^{-1}$, Cd $0.015 \mathrm{mg} \mathrm{L}^{-1}$, Cr $0.010 \mathrm{mg} \mathrm{L}^{-1}, \mathrm{Cu} 0.005 \mathrm{mg} \mathrm{L}^{-1}$, Fe $0.007 \mathrm{mg}$ $\mathrm{L}^{-1}$, Ni $0.0134 \mathrm{mg} \mathrm{L}^{-1}$, Pb $0.065 \mathrm{mg} \mathrm{L}^{-1}$, Zn $0.004 \mathrm{mg} \mathrm{L}^{-1}$ )

3) SPLP: Synthetic Precipitation Leaching Procedure

4) Area 1 and Area 2 of the Korea Allowable Effluent Water Quality Standards are classified according to the administrative district of South Korea.

Table 3. Crystal Structures Contained in the Mine Wastes Used in This Study

\begin{tabular}{|c|c|}
\hline $\begin{array}{c}\text { Mine } \\
\text { wastes }\end{array}$ & Crystal structures \\
\hline $\mathrm{Z}$ & $\begin{array}{c}\text { Quartz }\left(\mathrm{SiO}_{2}\right) \text {, Pyrite }\left(\mathrm{FeS}_{2}\right), \text { Pyroxomangite }\left(\mathrm{Mn}_{0.97} \mathrm{Mg}_{0.03} \mathrm{SiO}_{3}\right) \text {, Dolomite }\left(\mathrm{CaMg}\left(\mathrm{CO}_{3}\right)_{2} \text {, Merrihueite }\left((\mathrm{K}, \mathrm{Na})_{2}(\mathrm{Fe}, \mathrm{Mg})_{5} \mathrm{Si}_{12} \mathrm{O}_{30}\right) \text {, }\right. \\
\text { Chlorite-serpentine }\left((\mathrm{Mg}, \mathrm{Al})_{6}(\mathrm{Si}, \mathrm{Al})_{4} \mathrm{O}_{10}(\mathrm{OH})_{8}\right) \text {, Butlerite }\left(\mathrm{FeSO}_{4}(\mathrm{OH}) 2 \mathrm{H}_{2} \mathrm{O}\right) \text {, Tennantite }\left(\mathrm{Cu}_{6}\left(\mathrm{Cu}_{0.48} \mathrm{Fe}_{5.52}\right) \mathrm{As}_{4} \mathrm{~S}_{13}\right) \\
\left.\text { Unnamed mineral }\left(\left(\mathrm{K}, \mathrm{H}_{3} \mathrm{O}\right) \mathrm{Al}_{2} \mathrm{Si}_{3} \mathrm{AlO}_{10}(\mathrm{OH})_{2}\right)\right)\end{array}$ \\
\hline M & $\begin{array}{c}\text { Grossular }\left(\mathrm{Ca}_{3} \mathrm{Al}_{2}\left(\mathrm{SiO}_{4}\right)_{3}\right) \text {, Chlorite-serpentine }\left((\mathrm{Mg}, \mathrm{Al})_{6}(\mathrm{Si}, \mathrm{Al})_{4} \mathrm{O}_{10}(\mathrm{OH})_{8}\right) \text {, Calcium magnesium }\left(\mathrm{CaMg}_{0.52} \mathrm{Fe}_{0.48}\left(\mathrm{Si}_{2} \mathrm{O}_{6}\right)\right) \\
\text { Clinochlore IIb-4 }\left(\mathrm{Mg}_{9.8} \mathrm{Al}_{1.6} \mathrm{Fe}_{0.6}\left(\mathrm{Si}_{6.32} \mathrm{Al}_{1.68} \mathrm{O}_{20.24}\right)(\mathrm{OH})_{15.72}\right) \text {, Meionite }\left((\mathrm{Ca}, \mathrm{Na})_{2}\left(\mathrm{Si}, \mathrm{Al}_{6} \mathrm{O}_{12}\left(\mathrm{CO}_{3}\right)_{0.5}\right)\right. \\
\text { Muscovite-3T }\left((\mathrm{K}, \mathrm{Na})(\mathrm{Al}, \mathrm{Mg}, \mathrm{Fe})_{2}\left(\mathrm{Si}_{3.1} \mathrm{Al}_{0.9}\right) \mathrm{O}_{10}(\mathrm{OH})_{2}\right) \text {, Pargasite }\left(\mathrm{Na}_{3.38} \mathrm{Ca}_{1.7} \mathrm{Mg}_{3.34} \mathrm{Fe}_{1.77}\left(\mathrm{Al}_{1.8} \mathrm{Si}_{6.2}\right) \mathrm{O}_{23}(\mathrm{OH})\right) \\
\text { Heptairon tetrakis }\left(\mathrm{Fe}_{7}\left(\mathrm{P}_{2} \mathrm{O}_{7}\right)_{4}\right)\end{array}$ \\
\hline $\mathrm{Y}$ & $\begin{array}{l}\text { Biotite }\left(\mathrm{KFeMg}_{2}\left(\mathrm{AlSi}_{3} \mathrm{O}_{10}\right)(\mathrm{OH})_{2}\right) \text {, Magnesioriebeckite }\left((\mathrm{Na}, \mathrm{Ca})_{2}(\mathrm{Mg}, \mathrm{Fe})_{5} \mathrm{Si}_{8} \mathrm{O}_{22}(\mathrm{OH})_{2}\right) \\
\text { Clinochlore-1M } 1 \mathrm{Ilb} \text {, ferroan }\left((\mathrm{Mg}, \mathrm{Fe})_{6}\left(\mathrm{Si}, \mathrm{Al}_{4} \mathrm{O}_{10}(\mathrm{OH})_{8}\right) \text {, Laumontite }\left(\mathrm{Ca}_{4} \mathrm{~A}_{18} \mathrm{Si}_{16} \mathrm{O}_{48} 14 \mathrm{H}_{2} \mathrm{O}\right) \text {, Bementite }\left(\mathrm{Mn}_{8} \mathrm{Si}_{6} \mathrm{O}_{15}(\mathrm{OH})_{10}\right) \text {, }\right. \\
\left.\text { Cummingtonite manganonaon }\left(\mathrm{Na}_{0.1} \mathrm{Ca}_{0.4} \mathrm{Mg}_{5.6} \mathrm{Mn}_{1.0} \mathrm{Si}_{8} \mathrm{O}_{22}(\mathrm{OH})_{2}\right) \text {, Unnamed mineral ((Mn, } \mathrm{Zn}_{3} \mathrm{Zn}_{2} \mathrm{AsO}_{4}(\mathrm{OH}, \mathrm{O})_{6}\right)\end{array}$ \\
\hline $\mathrm{H}$ & $\begin{array}{c}\text { Diopside }\left(\mathrm{CaMg}\left(\mathrm{Si}_{2} \mathrm{O}_{6}\right)\right) \text {, Actinolite }\left(\mathrm{Ca}_{2}(\mathrm{Mg}, \mathrm{Fe})_{5} \mathrm{Si}_{8} \mathrm{O}_{22}(\mathrm{OH})_{2}\right) \text {, Antigorite-8.0M }\left(\mathrm{Mg}_{3} \mathrm{Si}_{2} \mathrm{O}_{5}(\mathrm{OH})_{4}\right) \\
\text { Clinoclore }\left(\left(\mathrm{Mg}_{2.8} \mathrm{Fe}_{1.7} \mathrm{Al}_{1.2}\right)\left(\mathrm{Si}_{2.8} \mathrm{Al}_{1.2}\right) \mathrm{O}_{10}(\mathrm{OH})_{8}\right), \text { Mutinaite }\left(\mathrm{Al}_{2} \mathrm{O}_{3} 54 \mathrm{SiO}_{2}\right) \\
\text { Cummingtonite manganoan }\left(\mathrm{Na}_{0.1} \mathrm{Ca}_{0.4} \mathrm{Mg}_{5.6} \mathrm{Mn}_{1.0} \mathrm{Si}_{8} \mathrm{O}_{22}(\mathrm{OH})_{2}\right)\end{array}$ \\
\hline
\end{tabular}

heavy metal leachability from the mine waste than the total metal contents. Even though the heavy metal concentrations of the leachate from the mine wastes met the regulations, the combined toxic effects of trace amounts of heavy metals in the leachates could still exhibit toxic effects on aquatic organisms
[22]. The toxic effects of the leachates on D. magna in TU were lower than the Korea Allowable Effluent Water Quality Standards for all the areas (TU $<1$ or $<2$ ) (Table 2). All the four mine waste samples tested in this study satisfied the regulations on the leachates, indicating that they can be reused. 
Table 4. Exchangeable, Carbonate-bound, and Iron and Manganese Oxides-bound Fractions of Heavy Metals in the Z Mine Waste Determined by Using the Tessier's Sequential Extraction Procedure

\begin{tabular}{|c|c|c|c|c|}
\hline Heavy metal & $\begin{array}{l}\text { Exchangeable (F1) } \\
\quad\left(\mathrm{mg} \mathrm{kg}^{-1}\right)\end{array}$ & $\begin{array}{l}\text { Carbonate-bound (F2) } \\
\left(\mathrm{mg} \mathrm{kg}^{-1}\right)\end{array}$ & $\begin{array}{l}\text { Iron and manganese oxides-bound (F3) } \\
\qquad\left(\mathrm{mg} \mathrm{kg}^{-1}\right)\end{array}$ & $\begin{array}{l}\text { Ratio of the sum of F1 and } \\
\text { F2 and the total content (\%) }\end{array}$ \\
\hline As & 134 & ND & 454 & 0.29 \\
\hline $\mathrm{Pb}$ & 764 & ND & 1,288 & 28 \\
\hline $\mathrm{Cd}$ & 8 & ND & 27 & 0.35 \\
\hline $\mathrm{Zn}$ & 226 & 7 & 403 & 1.6 \\
\hline $\mathrm{Cu}$ & 6 & ND & 3 & 0.92 \\
\hline $\mathrm{Ni}$ & ND & ND & ND & $\mathrm{ND}$ \\
\hline $\mathrm{Cr}$ & $\mathrm{ND}$ & ND & 17 & ND \\
\hline
\end{tabular}

ND: Not determined, Less than the detection limit

\subsection{Human Health Risk Assessment for Workers in Industrial Areas Where the Mine Wastes Are Reused}

The ingestion of soil is the major exposure pathway for heavy metal contaminated soils [23], so the intake of mine wastes via oral ingestion can be considered as the major exposure pathway for workers at mine sites. In addition to this, the exposure through inhalation of fugitive dust can be considered. Carcinogenic risk (CR) and non-carcinogenic risk (i.e., sum of Hazard Quotient (HQ) or Hazard Index (HI)) of each metal in mine wastes can be calculated using Eq. (1)-(7) considering an average daily dose (ADD) via ingestion and dermal contact or an average daily exposure (ADE) via inhalation and toxicity values [24, 25]. The input parameters and exposure factors used in risk calculation are shown in Table 5 .

Ingestion of mine wastes: ADD

$$
=(\mathrm{Cs} \times \mathrm{FI} \times \mathrm{IR} \times \mathrm{EF} \times \mathrm{ED}) /(\mathrm{BW} \times \mathrm{AT})
$$

Dermal contact with mine wastes: ADD

$=\left(\mathrm{Cs} \times \mathrm{AF} \times \mathrm{ABS}_{\mathrm{D}} \times \mathrm{SA} \times \mathrm{EF} \times \mathrm{ED}\right) /(\mathrm{BW} \times \mathrm{AT})$

Inhalation of fugitive dust: $\mathrm{ADE}$

$=(\mathrm{Cs} \times \mathrm{TSP} \times \mathrm{frs} \times \mathrm{FR} \times \mathrm{EF} \times \mathrm{ED}) /(\mathrm{AT})$

CR for ingestion of and dermal contact with mine wastes: $\mathrm{CR}=\mathrm{ADD} \times \mathrm{SF}$

CR for inhalation of fugitive dust: CR $=\mathrm{ADE} \times \mathrm{IUR}$

Non-CR for ingestion of and dermal contact with mine wastes: $\mathrm{HQ}=\mathrm{ADD} / \mathrm{RfD}_{\mathrm{o}}$

Non-CR for inhalation of fugitive dust: HQ $=\mathrm{ADD} / \mathrm{RfC}$

where ADD: average daily dose $\left(\mathrm{mg} \mathrm{kg}^{-1} \mathrm{~d}^{-1}\right)$; Cs: total content of metal ( $\mathrm{mg} \mathrm{kg}^{-1}$ ); FI: bioavailable fraction (\%); IR: ingestion rate $\left(\mathrm{mg} \mathrm{d}^{-1}\right)$; EF: exposure frequency (day $\left.\mathrm{y}^{-1}\right)$; ED: exposure duration (y); BW: body weight (kg); AT: averaging time (d); AF: Mine waste-to-skin adherence factor $\left(\mathrm{mg} \mathrm{cm}^{-2}\right) ; \mathrm{ABS}_{\mathrm{D}}$ : Dermal absorption factor (dimensionless); SA: Skin surface area $\left(\mathrm{cm}^{2}\right.$ $\left.\mathrm{d}^{-1}\right)$; ADE: average daily exposure $\left(\mathrm{mg} \mathrm{kg}^{-1} \mathrm{~d}^{-1}\right)$; TSP: Total suspended particle $\left(\mathrm{mg} \mathrm{m}^{-3}\right)$; frs: Fraction of mine waste in air (dimensionless); FR: Retention factor of mine waste in lungs (dimensionless); CR: Carcinogenic risk (dimensionless); SF: Slope factor $\left(\left(\mathrm{mg}(\mathrm{kg} \mathrm{d})^{-1}\right)^{-1}\right)$; IUR: Inhalation unit risk factor $\left(\left(\mu \mathrm{m} \mathrm{m} \mathrm{m}^{-3}\right)^{-1}\right)$; HQ: Hazard quotient (dimensionless); $\mathrm{RfD}_{\mathrm{o}}$ : Reference dose for oral exposure $\left(\mathrm{mg}\left(\mathrm{kg} \mathrm{d}^{-1}\right)\right.$; RfC: Reference concentration for inhalation $\left(\mathrm{mg} \mathrm{m}^{-3}\right)$.

Previous studies reported that there is a linear relationship between the in vitro SBRC extracted $\mathrm{As}, \mathrm{Pb}$, and Cd concentrations and the in vivo relative bioavailabilities [26-28]. Similarly, the SBRC extraction method was used to investigate the $\mathrm{Zn}$ bioavailability of the $\mathrm{Zn}$ contaminated samples [29-31]. Therefore, the SBRC extracted heavy metal concentrations were used to calculate the bioavailable fractions of heavy metals in the mine waste samples (i.e., FI in Eq. (1)). Table 6 shows the SBRC extracted heavy metal concentrations and the FI values of each heavy metal of each mine waste sample.

Carcinogenic risk is a probability of an individual developing cancer from carcinogenic hazards accounted for lifetime, and the acceptable range of carcinogenic risk is between 1.0E-06 and 1.0E-04. In addition, it is widely accepted that there is non-carcinogenic risk if $\mathrm{HI}$ is greater than $1.0 \mathrm{E}+00$. The risk calculation results are shown in Table 7. Among the four mine waste samples, only the $\mathrm{Z}$ mine waste and the $\mathrm{M}$ mine waste had risks. The $\mathrm{Z}$ mine waste had carcinogenic risk (i.e., CR value between 1.0E-06 and 1.0E-04) and non-carcinogenic risk (i.e., HI greater than 1.0E+00) (Table 7) for workers at mining sites. Similarly, the $\mathrm{M}$ mine waste had carcinogenic risk with the CR value of 8.6E-06 (Table 7). Among the heavy metals contained in the mine waste samples, As, $\mathrm{Cd}, \mathrm{Cr}, \mathrm{Ni}$, and $\mathrm{Pb}$ contributed to carcinogenic risk, and $\mathrm{As}, \mathrm{Cd}, \mathrm{Cr}, \mathrm{Cu}, \mathrm{Ni}, \mathrm{Pb}$, and $\mathrm{Zn}$ contributed to non-carcinogenic risk. The carcinogenic risk exhibited by the $\mathrm{Z}$ and $\mathrm{M}$ mine waste samples can be attributed to As. The CR value of As in the $\mathrm{Z}$ mine waste was $8.8 \mathrm{E}-04$, while the sum of the CR values for the other carcinogenic heavy metals (i.e., $\mathrm{Cd}, \mathrm{Cr}, \mathrm{Ni}$, and $\mathrm{Pb}$ ) in the $\mathrm{Z}$ mine waste was 6.6E-07. The high $\mathrm{HI}$ value of the $\mathrm{Z}$ mine waste can be attributed to As and Cd (Table 1). The HQ values for As and Cd were 2.8E+01 and $1.7 \mathrm{E}+00$, respectively, and these were relatively higher than 
Table 5. Input Parameters and Exposure Factors Used in This Study for Human Health Risk Assessment

\begin{tabular}{|c|c|c|c|}
\hline & Units & Value & Reference \\
\hline \multicolumn{4}{|l|}{ Input parameters } \\
\hline $\mathrm{C}_{\mathrm{S}}$ (Total content of metal) & $\mathrm{mg} \mathrm{kg}{ }^{-1}$ & - & Table 1 \\
\hline IR (Mine waste ingestion rate) & $\mathrm{mg} \mathrm{d}^{-1}$ & 50 & [1] \\
\hline FI (Bioavailable fraction) & $\%$ & - & Table 6 \\
\hline EF (Exposure frequency) & day $\mathrm{y}^{-1}$ & 100 & {$[2]$} \\
\hline ED (Exposure duration) & $\mathrm{y}$ & 25 & {$[1]$} \\
\hline AF (Mine waste-to-skin adherence factor) & $\mathrm{mg} \mathrm{cm}{ }^{-2}$ & 0.07 & {$[1]$} \\
\hline SA (Skin surface area) & $\mathrm{cm}^{2} \mathrm{~d}^{-1}$ & 4,271 & {$[1]$} \\
\hline TSP (Total suspended particle) & $\mathrm{mg} \mathrm{m}^{-3}$ & 0.07 & {$[1]$} \\
\hline frs (Fraction of mine waste in air) & - & 0.5 & {$[1]$} \\
\hline FR (Retention factor of mine tailings in lungs) & - & 0.75 & {$[1]$} \\
\hline $\mathrm{CF}$ (Conversion factor) & $\mathrm{kg} \mathrm{mg}^{-1}$ & $10^{-6}$ & - \\
\hline BW (Average body weight) & $\mathrm{kg}$ & 62.8 & {$[1]$} \\
\hline $\mathrm{AT}_{\mathrm{C}}$ (Averaging time for carcinogens) & $\mathrm{d}$ & 28,470 & {$[2]$} \\
\hline $\mathrm{AT}_{\mathrm{n}}$ (Averaging time for non-carcinogens) & $\mathrm{d}$ & 9,125 & {$[2]$} \\
\hline $\mathrm{CR}_{\mathrm{w}}$ (Daily intake of groundwater) & $\mathrm{L} \mathrm{d}^{-1}$ & $\begin{array}{c}\text { Adult: } 2 \\
\text { Children: } 1\end{array}$ & {$[1]$} \\
\hline BCF (Bio-concentration factor) & mg kg-crop ${ }^{-1}\left(\mathrm{mg} \mathrm{kg}_{\text {-soil }}{ }^{-1}\right)^{-1}$ & $\begin{array}{l}\text { As: } 0.03 \\
\text { Cr: } 0.02 \\
\text { Pb: } 0.03\end{array}$ & {$[1]$} \\
\hline $\mathrm{CR}_{\mathrm{p}}$ (Daily intake of crop (leaf vegetable)) & $\mathrm{kg} \mathrm{d}^{-1}$ & $\begin{array}{l}\text { Adult: } 0.027 \\
\text { Child: } 0.008\end{array}$ & {$[1]$} \\
\hline
\end{tabular}

\section{Exposure factors}

\begin{tabular}{|c|c|c|c|}
\hline SF (Slope factor) & $\left(\mathrm{mg}(\mathrm{kg} \mathrm{d})^{-1}\right)^{-1}$ & $\begin{array}{l}\text { As: } 1.50 \mathrm{E}+00 \\
\mathrm{~Pb}: 8.50 \mathrm{E}-03\end{array}$ & [2] \\
\hline $\mathrm{ABS}_{\mathrm{D}}$ (Dermal absorption factor) & - & $\begin{array}{l}\text { As: } 3.0 \mathrm{E}-02 \\
\text { Cd: } 1.0 \mathrm{E}-03\end{array}$ & [2] \\
\hline IUR (Inhalation unit risk factor) & $\left.(\mu \mathrm{m} \mathrm{m})^{-3}\right)^{-1}$ & $\begin{array}{l}\text { As: } 4.3 \mathrm{E}-03 \\
\text { Cd: } 1.8 \mathrm{E}-03 \\
\text { Cr: } 8.4 \mathrm{E}-02 \\
\text { Ni: } 2.6 \mathrm{E}-04 \\
\text { Pb: } 1.2 \mathrm{E}-05\end{array}$ & [2] \\
\hline $\mathrm{RfD}_{\mathrm{O}}$ (Reference dose for oral exposure) & $\operatorname{mg}(\mathrm{kg} \mathrm{d})^{-1}$ & $\begin{array}{l}\text { As: } 3.0 \mathrm{E}-04 \\
\mathrm{Cd}: 1.0 \mathrm{E}-03 \\
\mathrm{Cu}: 4.0 \mathrm{E}-02 \\
\mathrm{~Pb}: 3.6 \mathrm{E}-03 \\
\mathrm{Zn}: 3.0 \mathrm{E}-01\end{array}$ & [2] \\
\hline RfC (Reference concentration for inhalation) & $\mathrm{mg} \mathrm{m}^{-3}$ & $\begin{array}{l}\text { As: } 1.5 \mathrm{E}-05 \\
\text { Cd: } 1.0 \mathrm{E}-05 \\
\text { Cr: } 1.0 \mathrm{E}-04 \\
\text { Ni: } 9.0 \mathrm{E}-05\end{array}$ & [2] \\
\hline
\end{tabular}

1) (KMOE 2015)

2) (USEPA 2011)

the sum of the HQ values for the other non-carcinogenic heavy metals (i.e., $\mathrm{Cr}, \mathrm{Cu}, \mathrm{Ni}, \mathrm{Pb}$, and $\mathrm{Zn}$ ), which was $6.9 \mathrm{E}-02$. The high $\mathrm{CR}$ value of the $\mathrm{M}$ mine waste sample can also be explained by the relatively higher CR value for As, which was $8.4 \mathrm{E}-06$.
Also, among the three exposure routes considered in the risk calculation, the route considering the dermal contact with mine wastes was the major route for the carcinogenic risk for both the $\mathrm{Z}$ and $\mathrm{M}$ mine wastes. On the other hand, the human health 
Won Jung Ju et al.

Table 6. Bioavailable Metal Concentrations and Bioavailable Fractions (FI) Determined by Using the Solubility/Bioavailability Research Consortium (SBRC) Method

\begin{tabular}{ccccccccc}
\hline & & As & Cd & Cu & Cr & Pb & Zn \\
\hline $\mathrm{Z}$ & $\mathrm{SBRC}$ & $\left(\mathrm{mg} \mathrm{kg}^{-1}\right)$ & $257.9 \pm 44.9$ & $14.5 \pm 2.8$ & $22.8 \pm 6.3$ & $3.4 \pm 0.1$ & $1,056.7 \pm 119.0$ & $422.4 \pm 56.0$ \\
& $\mathrm{FI}^{1)}$ & $(\%)$ & 0.568 & 0.632 & 3.50 & 2.86 & 39.6 & 2.84 \\
\hline $\mathrm{M}$ & $\mathrm{SBRC}$ & $\left(\mathrm{mg} \mathrm{kg}^{-1}\right)$ & $8.6 \pm 4.7$ & $\mathrm{ND}$ & $3.2 \pm 0.5$ & $11.9 \pm 0.3$ & $3.5 \pm 0.3$ & $26.8 \pm 2.0$ \\
& $\mathrm{FI}^{1)}$ & $(\%)$ & 2.14 & - & 2.00 & 1.87 & 0.298 & 1.15 \\
\hline $\mathrm{Y}$ & $\mathrm{SBRC}^{1)}$ & $\left(\mathrm{mg} \mathrm{kg}^{-1}\right)$ & $\mathrm{ND}$ & $\mathrm{ND}$ & $7.2 \pm 0.4$ & $2.5 \pm 0.5$ & $9.1 \pm 2.8$ & $27.4 \pm 0.1$ \\
& $\mathrm{FI}^{1)}$ & $(\%)$ & - & - & 27.0 & 8.08 & 10.5 & 7.03 \\
\hline $\mathrm{H}$ & $\mathrm{SBRC}^{1)}$ & $\left(\mathrm{mg} \mathrm{kg}^{-1}\right)$ & $\mathrm{ND}$ & $1.0 \pm 0.5$ & $\mathrm{ND}$ & $3.8 \pm 0.1$ & $7.7 \pm 1.2$ & $67.1 \pm 5.5$ \\
& $\mathrm{FI}^{1)}$ & $(\%)$ & - & 7.93 & - & 2.69 & 0.651 & 3.75 \\
\hline
\end{tabular}

1) FI: (concentration of metal in SBRC leachate)/(total content of the metal)

Table 7. Human Health Risk on Workers in Industrial Areas Where Mine Wastes Are Reused

\begin{tabular}{ccccc}
\hline Mine waste sample & $\mathbf{Z}$ & $\mathbf{M}$ & $\mathbf{Y}$ & $\mathbf{H}$ \\
\hline Carcinogenic risk (CR) & $8.8 \mathrm{E}-04$ & $8.6 \mathrm{E}-06$ & $1.2 \mathrm{E}-08$ & $3.3 \mathrm{E}-08$ \\
Non-carcinogenic risk (HI) & $3.0 \mathrm{E}+01$ & $3.2 \mathrm{E}-01$ & $3.0 \mathrm{E}-03$ & $3.5 \mathrm{E}-02$ \\
\hline
\end{tabular}

risks calculated for workers at the $\mathrm{Y}$ and $\mathrm{H}$ mine sites showed that there is neither carcinogenic risk nor non-carcinogenic risk at the $\mathrm{Y}$ and $\mathrm{H}$ mine sites (Table 7). The $\mathrm{CR}$ values were lower than $1.0 \mathrm{E}-6$ and the HI values were lower than $1.0 \mathrm{E}+00$.

The results indicate that when the $\mathrm{Z}$ and $\mathrm{M}$ mine waste samples are reused in industrial areas, the workers at the mine sites who deal with the mine wastes or in the industrial areas where the mine wastes are reused are likely to have carcinogenic and non-carcinogenic risks largely due to As in the mine waste samples via dermal contact. If the $\mathrm{Z}$ and $\mathrm{M}$ mine waste samples are to be reused in industrial areas, strategies that can prevent the dermal contact of the mine waste samples such as the use of protective clothing can be adopted for workers. Also, the bioavailable fraction of As and $\mathrm{Cd}$ in the $\mathrm{Z}$ mine waste sample and $A s$ in the $\mathrm{M}$ mine waste sample can be reduced by applying techniques such as immobilization. On the other hand, the Y and $\mathrm{H}$ mine wastes might be reused without imposing human health risks on the workers at mine sites or in the industrial areas where the mine wastes are reused.

\subsection{Human Health Risk Assessment for Residents in Residential Areas Where the Mine Wastes Are Reused}

The human health risks on residents in residential areas where the $\mathrm{Y}$ or $\mathrm{H}$ mine wastes are used as construction materials were calculated since the $\mathrm{Y}$ and $\mathrm{H}$ mine wastes did not impose carcinogenic or non-carcinogenic risks. For human health risk at residential areas, exposure through ingestion of crops grown on the mine wastes (i.e., worst case scenario) and exposure through ingestion of groundwater were considered additionally. Carcinogenic risk and non-carcinogenic risk of each metal in the mine waste samples can be calculated using Eq. (1)-(12) considering the ADD via oral ingestion, dermal contact, ingestion of crop, and ingestion of groundwater and the $\mathrm{ADE}$ via inhalation of fugitive dust [24, 25]. The input parameters and exposure factors used in risk calculation are shown in Table 5 .

Ingestion of crop grown on mine wastes: $\mathrm{ADD}$ $=\left(\mathrm{Cs} \times \mathrm{AF} \times \mathrm{BCF} \times \mathrm{CR}_{\mathrm{p}} \times \mathrm{SA} \times \mathrm{EF} \times \mathrm{ED}\right) /(\mathrm{BW} \times \mathrm{AT})$

Ingestion of groundwater: ADD $=\left(\mathrm{C}_{\mathrm{w}} \times \mathrm{CR}_{\mathrm{w}} \times \mathrm{EF} \times \mathrm{ED}\right) /(\mathrm{BW} \times \mathrm{AT})$

CR for ingestion of crop grown on mine wastes: CR $=\mathrm{ADD} \times \mathrm{SF}$

CR for ingestion of groundwater: CR $=\mathrm{ADD} \times \mathrm{IUR}$

Non-CR for ingestion of crop grown on mine wastes and of groundwater: $\mathrm{HQ}=\mathrm{ADD} / \mathrm{RfD}_{\mathrm{O}}$

where ADD: average daily dose $\left(\mathrm{mg} \mathrm{kg}^{-1} \mathrm{~d}^{-1}\right)$; Cs: total content of metal ( $\left.\mathrm{mg} \mathrm{kg}^{-1}\right)$; AF: Mine waste-to-skin adherence factor (mg $\mathrm{cm}^{-2}$ ); BCF: Bio-concentration factor (mg kg-crop ${ }^{-1}$ (mg $\mathrm{kg}$ soil $\left.\left.^{-1}\right)^{-1}\right)$; $\mathrm{CR}_{\mathrm{p}}$ : Daily intake of crop $\left(\mathrm{kg} \mathrm{d}^{-1}\right)$; SA: Skin surface area $\left(\mathrm{cm}^{2} \mathrm{~d}^{-1}\right)$; EF: exposure frequency (day $\mathrm{y}^{-1}$ ); ED: exposure duration (y); BW: body weight (kg); AT: averaging time (d); $\mathrm{C}_{\mathrm{w}}$ : metal concentration in groundwater $\left(\mathrm{mg} \mathrm{L}^{-1}\right)$; $\mathrm{CR}_{\mathrm{w}}$ : Daily intake of groundwater $\left(\mathrm{L} \mathrm{d}^{-1}\right)$; CR: Carcinogenic risk (dimensionless); SF: Slope factor $\left(\left(\mathrm{mg}\left(\mathrm{kg} \mathrm{d}^{-1}\right)^{-1}\right)\right.$; IUR: Inhalation unit risk factor $\left(\left(\mu \mathrm{m} \mathrm{m} \mathrm{m}^{-3}\right)^{-1}\right)$; HQ: Hazard quotient (dimensionless); RfD Reference dose for oral exposure (mg $\left(\mathrm{kg} \mathrm{d}^{-1}\right)$.

Table 8 shows the human health risks on residents in residential areas where the $\mathrm{Y}$ and $\mathrm{H}$ mine wastes are reused. The CR values for the Y mine waste reused area (i.e., 4.7E-06) and the $\mathrm{H}$ mine waste reused area (i.e., 6.8E-06) both exceeded 1.0E-6 indicating that there is a carcinogenic risk (Table 8). The major exposure route of heavy metals in the $\mathrm{Y}$ and the $\mathrm{H}$ mine wastes was the ingestion of crops grown on the mine wastes. The major 
Table 8. Human Health Risk on Residents in Residential Areas Where Mine Wastes Are Reused

\begin{tabular}{|c|c|c|c|c|c|c|c|c|}
\hline & & & $\begin{array}{l}\text { Ingestion of } \\
\text { mine waste }\end{array}$ & $\begin{array}{l}\text { Ingestion of } \\
\text { crop grown on } \\
\text { mine waste }\end{array}$ & $\begin{array}{c}\text { Dermal } \\
\text { contact with } \\
\text { mine waste }\end{array}$ & $\begin{array}{l}\text { Inhalation of } \\
\text { fugitive dust }\end{array}$ & $\begin{array}{l}\text { Ingestion of } \\
\text { groundwater }\end{array}$ & Total \\
\hline \multirow{6}{*}{$\mathrm{Y}$} & \multirow{3}{*}{$\begin{array}{l}\text { Carcinogenic risk } \\
\text { (CR) }\end{array}$} & Adult & $1.9 \mathrm{E}-08$ & 3.6E-06 & $0.0 \mathrm{E}+00$ & $2.1 \mathrm{E}-08$ & $0.0 \mathrm{E}+00$ & 3.7E-06 \\
\hline & & Children & $4.0 \mathrm{E}-08$ & 9.7E-07 & $0.0 \mathrm{E}+00$ & 5.1E-09 & $0.0 \mathrm{E}+00$ & $1.0 \mathrm{E}-06$ \\
\hline & & Total & 5.9E-08 & $4.6 \mathrm{E}-06$ & $0.0 \mathrm{E}+00$ & $2.6 \mathrm{E}-08$ & $0.0 \mathrm{E}+00$ & 4.7E-06 \\
\hline & \multirow{3}{*}{$\begin{array}{l}\text { Non-carcinogenic } \\
\text { risk }(\mathrm{HI})\end{array}$} & Adult & 2.8E-03 & 5.3E-02 & $0.0 \mathrm{E}+00$ & 7.9E-03 & $0.0 \mathrm{E}+00$ & $6.4 \mathrm{E}-02$ \\
\hline & & Children & $2.4 \mathrm{E}-02$ & 6.7E-02 & $0.0 \mathrm{E}+00$ & 7.9E-03 & $0.0 \mathrm{E}+00$ & 9.9E-02 \\
\hline & & Total & 2.7E-02 & $1.2 \mathrm{E}-01$ & $0.0 \mathrm{E}+00$ & $1.6 \mathrm{E}-02$ & $0.0 \mathrm{E}+00$ & 1.6E-01 \\
\hline \multirow{6}{*}{$\mathrm{H}$} & \multirow{3}{*}{$\begin{array}{l}\text { Carcinogenic risk } \\
\text { (CR) }\end{array}$} & Adult & $1.6 \mathrm{E}-08$ & $5.2 \mathrm{E}-06$ & $0.0 \mathrm{E}+00$ & 9.6E-08 & $0.0 \mathrm{E}+00$ & $5.3 \mathrm{E}-06$ \\
\hline & & Children & 3.4E-08 & $1.4 \mathrm{E}-06$ & $0.0 \mathrm{E}+00$ & 2.3E-08 & $0.0 \mathrm{E}+00$ & $1.5 \mathrm{E}-06$ \\
\hline & & Total & $5.0 \mathrm{E}-08$ & 6.6E-06 & $0.0 \mathrm{E}+00$ & $1.2 \mathrm{E}-07$ & $0.0 \mathrm{E}+00$ & $6.8 \mathrm{E}-06$ \\
\hline & \multirow{3}{*}{$\begin{array}{l}\text { Non-carcinogenic } \\
\text { risk }(\mathrm{HI})\end{array}$} & Adult & 3.5E-03 & 3.5E-01 & 5.7E-05 & $1.2 \mathrm{E}-01$ & $0.0 \mathrm{E}+00$ & 4.7E-01 \\
\hline & & Children & $3.1 \mathrm{E}-02$ & $4.0 \mathrm{E}-01$ & $2.6 \mathrm{E}-04$ & $1.2 \mathrm{E}-01$ & $0.0 \mathrm{E}+00$ & 5.5E-01 \\
\hline & & Total & 3.5E-02 & 7.4E-01 & $3.2 \mathrm{E}-04$ & $2.4 \mathrm{E}-01$ & $0.0 \mathrm{E}+00$ & $1.0 \mathrm{E}+00$ \\
\hline
\end{tabular}

contributor to the $\mathrm{CR}$ of the $\mathrm{Y}$ and $\mathrm{H}$ mine waste samples was $\mathrm{Cr}$ - the CR value for $\mathrm{Cr}$ in the Y mine waste sample was 4.2E-06, while it was $5.1 \mathrm{E}-06$ in the $\mathrm{H}$ mine waste sample. However, this route assumed that the crops are grown on soil consisting of only the mine waste samples to simulate the worst case scenario, and this will not happen in reality. Also, the exposure via ingestion of mine wastes or inhalation of fugitive dust is unlikely if the mine wastes are reused as construction materials that do not have direct contact with residents. The $\mathrm{Y}$ and $\mathrm{H}$ mine waste samples did not impose non-carcinogenic risks on residents in residential areas (Table 8). The results suggest that the $\mathrm{Y}$ and $\mathrm{H}$ mine waste samples may impose risks if reused in residential areas. If the $\mathrm{Y}$ and $\mathrm{H}$ mine wastes are to be reused in residential areas, the reuse of mine wastes as filling materials of agricultural areas should be avoided or Cr treatment may be necessary.

\section{Conclusions}

The metal mine waste samples used in this study contained several heavy metals such as As, Cd, and Cr that can impose human health risks. However, the heavy metal concentrations in the leachates generated via the STM and SPLP showed that the heavy metal concentrations in the leachates did not depend on the total heavy metal contents of the mine wastes. This can largely be attributed to the crystal structures of the mine wastes. The leachates studied did not have toxic effects on D. magna. The leaching test-based assessment can be used to screen out the potentially reusable mine wastes from those that are not reusable. This can be followed by the risk assessment to assess the risk associated with reusing mine wastes in industrial or residential areas. If the potentially reusable mine wastes do not impose any human health risks, then they can be reused. If the potentially reusable mine wastes may impose risks, then they can be discarded or they can be reused after preventing the major risk route and/or treating the heavy metal of concern. With this two-stage assessment method for mine wastes, the reusability of mine wastes can be determined, and this will contribute towards protecting environment and resources.

\section{Acknowledgments}

This research was supported by Basic Science Research Program through the National Research Foundation of Korea (NRF) funded by the Ministry of Science, ICT \& Future Planning (NRF2014R1A1A1003762 and NRF-2016R1D1A1A02936998). This work was also supported by Hankuk University of Foreign Studies Research Fund (2018).

\section{References}

1. Paek SH, Ko JI, Lee JS, Kwon HH. Current Status of mine's environmental pollution and prevention restoration technology. Geoenviron. Eng. 2008;9:8-18.

2. Karaka O, Reddy KR. Environmental assessment of mine tailings: Can-Etili Basin (Turkey) as a case study. International Multidisciplinary Scientific GeoConference: SGEM: Surveying Geology \& Mining Ecology Management. 2014;3:221-232.

3. Chung JH, Lee DY, Lee JJ. Heavy metal pollution status of the metal mine nearby residents. Seoul: Jipmoon Publishing Inc.; 2002.p. 13-14.

4. Ju WJ, Jho EH, Nam KP. From mine tailings to electricity using ecological function: Evaluation of increase in current density by increasing the oxidation rate of pyrite using iron oxidizing bacteria. Ecol. Resil. Infrastruct. 2014;1:19-24.

5. Ju WJ, Jho EH, Nam KP. Effect of pyrite and indigenous bacteria on electricity generation using mine tailings. Ecol. Resil. Infrastruct. 2015;2:93-98.

6. Ji SW, Yim GJ. Mine reclamation and its prevention 
technology. J. Korean Geosynthetics Soc. 2010;9:19-23.

7. Cobb GP, Sands K, Waters M, Wixson BG, Dorward-King E. Accumulation of heavy metals by vegetables grown in mine wastes. Environ. Toxicol. Chem. 2000;19:600-607.

8. Walker DJ, Clemente R, Bernal MP. Contrasting effects of manure and compost on soil $\mathrm{pH}$, heavy metal availability and growth of Chenopodium album L. in a soil contaminated by pyritic mine waste. Chemosphere 2004;57:215-224.

9. Xenidis A, Papassiopi N, Komnitsas K. Carbonate-rich mining tailings in Lavrion: Risk assessment and proposed rehabilitation schemes. Adv. Environ. Res. 2003;7:479-494.

10. Lee SW, Lee BT, Kim JY, Kim KW, Lee JS. Human risk assessment for heavy metals and As contamination in the abandoned metal mine areas, Korea. Environ. Monit. Assess. 2006;119:233-244.

11. Levei E, Frentiu T, Ponta M, Tanaselia C, Borodi G. Characterization and assessment of potential environmental risk of tailings stored in seven impoundments in the Aries river basin, Western Romania. Chem. Cent. J. 2013;7:1-14.

12. Shaw SC, Groat LA, Jambor JL, Blowes DW, Hanton-Fong CJ, Stuparyk RA. Mineralogical study of base metal tailings with various sulfide contents, oxidized in laboratory columns and field lysimeters. Environ. Geol. 1998;33:209-217.

13. USEPA. Method 3052 Microwave assisted acid digestion of siliceous and organically based matrices [Internet]. USEPA; 1996 [cited 15 December 2017]. Available from: https://www. epa.gov/sites/production/files/2015-12/documents/3052.pdf.

14. Tessier A, Campbell PGC, Bisson M. Sequential extraction procedure for the speciation of particulate trace metals. Anal. Chem. 1979;51:844-851.

15. KMOE (Korea Ministry of Environment). Effluent water quality standards. KMOE; 2014.

16. USEPA. Test methods for evaluating solid waste, physical/chemical methods, Method 1312: Synthetic Precipitation Leaching Procedure [Internet]. USEPA; 1994 [cited 29 November 2015]. Available from: https://www.epa.gov/ sites/production/files/2015-12/documents/1312.pdfabout Synthetic Precipitation Leaching Procedure/.

17. KMOE (Korea Ministry of Environment). Standard water quality test method No. 2017-65. KMOE; 2016.

18. KMOE (Korea Ministry of Environment). Korea standard test for solid waste No. 2014-31. KMOE; 2014.

19. Kelly ME, Brauning SE, Schoof RA, Ruby MV. Assessing oral bioavailability of metals in soil. Columbus, $\mathrm{OH}$ : Battelle Press; 2002.
20. KMOE (Korea Ministry of Environment). Assessment of soil environment No. 2015-64. KMOE; 2015.

21. Cappuyns V, Alian V, Vassilieva E, Swennen R. pH dependent leaching behavior of $\mathrm{Zn}, \mathrm{Cd}, \mathrm{Pb}, \mathrm{Cu}$ and As from mining wastes and slags: kinetics and mineralogical control. Waste Biomass Valori. 2014;5:355-368.

22. Nys C, Versieren L, Cordery KI, Blust R, Smolders E, De Schamphelaere KA. Systematic evaluation of chronic metal-mixture toxicity to three species and implications for risk assessment. Environ. Sci. Technol. 2017;51:4615-4623.

23. Ordóñez A, Álvarez R, Charlesworth S, De Miguel E, Loredo J. Risk assessment of soils contaminated by mercury mining, Northern Spain. J. Environ. Monit. 2011;13:128-136.

24. Meunier L, Walker SR, Wragg J, Parsons MB, Koch I, Jamieson $\mathrm{HE}$, Reimer KJ. Effects of soil composition and mineralogy on the bioaccessibility of arsenic from tailings and soil in gold mine districts of Nova Scotia. Environ. Sci. Technol. 2010;44:2667-2674.

25. USEPA. Exposure factors handbook EPA/600/R-090/052F [Internet]. USEPA; 2011 [cited 18 July 2016]. Available from: https:/hero.epa.gov/hero/index.cfm/project/page/project_ id/1854 about Exposure factors handbook/.

26. Juhasz AL, Weber J, Smith E, et al. Evaluation of SBRC-gastric and SBRC-intestinal methods for the prediction of in vivo relative lead bioavailability in contaminated soils. Environ. Sci. Technol. 2009;43:4503-4509.

27. Juhasz AL, Weber J, Smith E, et al. Assessment of four commonly employed in vitro arsenic bioaccessibility assays for predicting in vivo relative arsenic bioavailability in contaminated soils. Environ. Sci. Technol. 2009;43:9487-9494.

28. Juhasz AL, Weber J, Naidu R, et al. Determination of cadmium relative bioavailability in contaminated soils and its prediction using in vitro methodologies. Environ. Sci. Technol. 2010;44:5240-5247.

29. Hu X, Zhang Y, Ding Z, et al. Bioaccessibility and health risk of arsenic and heavy metals $(\mathrm{Cd}, \mathrm{Co}, \mathrm{Cr}, \mathrm{Cu}, \mathrm{Ni}, \mathrm{Pb}$, Zn and Mn) in TSP and PM2.5 in Nanjing, China. Atmos. Environ. 2012;57:146-152.

30. Molina RM, Schaider LA, Donaghey TC, Shine JP, Brain JD. Mineralogy affects geoavailability, bioaccessibility and bioavailability of zinc. Environ. Pollut. 2013;182:217-224.

31. Sialelli J, Davidson CM, Hursthouse AS, Ajmone-Marsan F. Human bioaccessibility of $\mathrm{Cr}, \mathrm{Cu}, \mathrm{Ni}, \mathrm{Pb}$ and $\mathrm{Zn}$ in urban soils from the city of Torino, Italy. Environ. Chem. Lett. 2011;9:197-202. 